\title{
Chilean scientists remaining in the country are labouring under very difficult circumstances which are mainly economic. Funds for research are very limited, and it is very difficult for these people to carry out experiments using modern techniques.
}

\author{
From Carlos Eyzaguirre, Chairman of \\ the Department of Physiology, Uni- \\ versity of Utah College of Medicine, \\ Salt Lake City, and Visiting Pro. \\ fessor, Department of Neurobiology, \\ Catholic University of Chile, Santiago.
}

I READ with interest a letter (Nature, March 29) signed by H. M. Gerschenfeld and others, regarding the situation of the academic community in Chile. It is intriguing and provoking since it shows a rather desperate situation: instances of police brutality, wholesale dismissals of faculty and students and a total disregard for academic freedoms and human rights on the part of the military government. The letter is inaccurate and the charges very serious. Thus, a reply is in order.

I started my academic career in Chile and went permanently to the United States about 17 years ago. Since then, I have returned to Chile many times for academic purposes and have continuously maintained close contacts with Chilean academics. At present I am a Visiting Professor of Neurobiology at the Catholic University and have been in the country since April. Thus, I feel better qualified to judge the present situation than the gentlemen signing the letter to Nature.

Dr Allende's Government started with high hopes for the underprivileged who are numerous in this country. Unfortunately, slowly and steadily things deteriorated to the point of chaos and anarchy. The universities were not immune to this decaying process: funds were drastically cut to the point where research came to a standstill. CONICYT (equivalent to the National Research Council), which actively supported research during the previous Frei administration, became a planning agency which developed a number of programmes more often than not politically motivated. The Academy of Sciences of the Instituto de Chile was left practically without funds. There was total lack of student discipline to the point where it was extremely difficult to conduct normal academic activities. In addition, there were frequent armed confrontations on the streets, incredible government corruption and, near the end, people had to queue for hours to get a few essentials such as bread, soap, fuel, cigarettes. In the middle of this lovely picture the military struck with vigour on September 11, 1973. Interestingly enough they were shot at by supposedly defenceless civilians. In the melee many people were killed (including soldiers and policemen) and mopping up operations continued for a while. In context, the military operation in Chile was not a palace coup but a civil war which, fortunately, lasted only a few days. Casualties were many, but they could have been much more numerous if the military had been less decisive.

No one denies that there have been mistakes, cases of police harshness and unfair firing of people from their jobs. Some of these unpleasant practices have, however, been corrected; the country is again at work with the consequent increase in productivity, there is more discipline and normal activities have resumed. The people have cooperated, not necessarily because of fear, but the coup had the acceptance of the majority of the people. In a country like this, with a profound democratic tradition, nobody can govern without popular acquiescence. The democratic process has not been restored yet. Congress and the political parties are in recess and the press is still quite cautious. There is, however, hope for the future and the military have promised full democracy as soon as possible, whenever that may be. Many people believe that these are not vacuous statements since the military in Chile have been and are civic minded. Proof of this is that they have supervised all elections since 1938, when under President Pedro Aguirre (head of a Popular Front coalition) they got that authority. This practice continued under $\mathrm{Dr}$ Allende and there is consensus that elections in Ohile have been generally fair.

Why did the military strike? They did so to restore the country to a more normal way of life, to eliminate the unconstitutional excesses of the previous government and the political, moral and economic chaos present in Chile at that time.

It was not an easy task, from a public relations point of view, since Dr Allende enjoyed great popularity in foreign countries. He was pictured as a democrat trying to reach socialism by peaceful and constitutional means, a David fighting the United States Goliath and opening new ways of government to improve the lot of the poor; in short, Sir Galahad under a poncho. Most of his countrymen saw him in a different light: a scheming, corrupt and manouvering politician trying to outflank the wishes of Congress and of the Courts and bribe the Armed Forces, and very incompetent in the business of running the country. Moreover, they resented the fact that Dr Castro and the Soviet Union had too much to say about national affairs. Some of these complaints were unfair since there was political and economic pressure from the United States and he had to turn somewhere for help. The fact remains, however, that he could not manage the affairs of the nation and Chile would have faced certain economic, moral and political ruin had he remained in power.

Soon after the military coup, the heads (rectors) of the different universities were fired by the government. They were replaced by retired senior armed forces officers. Also, an army general was made head of CONICYT. These appointments seem, on the surface, to go against traditional university procedures, at least in Chile where most university presidents have been academicians. In other countries such as the United States, university presidents vary from academic to scientific administrators (such as Dr Fletcher at the University of Utah and now head of NASA) or retired politicians or generals (Eisenhower at Columbia). Thus, the appointments of Admiral Swett as Rector of the Catholic University or General Ruiz at the University of Chile would not be too far from practices that are not unknown in the United States. The difference is that both Admiral Swett and General Ruiz were appointed very soon after the military takeover in Chile. Interestingly enough, Admiral Swett's appointment was confirmed by Cardinal Silva, head of the Catholic Church and Chancellor of the Catholic University.

The new university rectors faced several problems: (1) an unruly student body heavily loaded with Marxist activists. Some of them were not students in the traditional sense of being properly registered, attending classes, taking examinations and so on; (2) a 


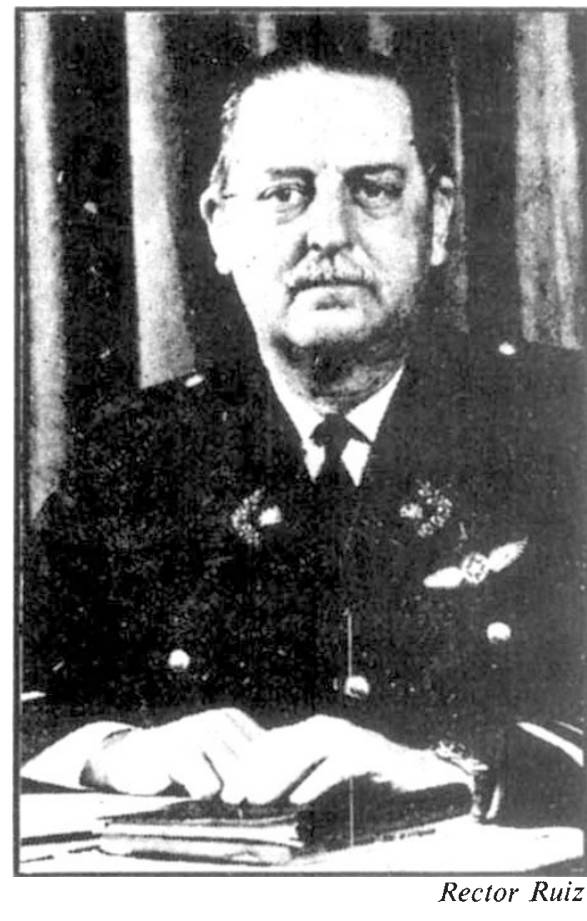

peculiar faculty, some members being almost exclusively interested in the propagation of Marxism and organising revolutionary and guerrilla activities. Some did not even have a BA degree. This situation became intolerable for some faculty members who left the country and sought employment abroad; (3) chaotic finances which prevented normal university activities and the payment of adequate personnel salaries. One wonders if any university in a civilised country would have tolerated that situation for long.

The rectors had to act and they did the following: (1) students at some universities had to re-register. Students who did not qualify as such in the traditional sense (taking a certain number of courses for credit, passing qualifying examinations and so on were dismissed. This weeded out the purely political 'students', but is this so terribly unfair? At the Catholic University, however, all of 11,500 students remained and no one was required to re-register. (2) The faculty went through the same screening procedure. Those who did not qualify for lack of degrees or for being exclusively political activists were dismissed. This procedure would have been applied in any university under normal circumstances. Left-leaning faculty members who carried out their duties of teaching and research during Allende's government were not asked to resign. Many of them are still in Chile. Some have left because of their inability to come to terms with the present government. This is their prerogative and their exit from the country has not been impeded.

Wholesale executions of faculty or scientists because of political views have not occurred. Very few fell either immediately after or during the coup because, allegedly, they were caught either shooting at soldiers, carrying arms or actively participating in the organisation of revolutionary activities. For the the past several months, however, there has been no indication that such a thing has occurred again. Some academicians, deeply involved in extremist activities were detained for investigation. Most of them have been freed and many have returned to jobs in the same or different universities. Others have either not returned to the country or have sought asylum. There are charges against some of these people and if they return they will face legal prosecution. But prosecution is one thing and persecution another. Some academicians have had trouble with the police because of denunciations by neighbours or colleagues. These people have been investigated ployed again in the same or similar jobs.

The question is then, what constitutes an offence leading to academic dismissal that would prevent further academic employment? I am not privy to the deliberations of the rectors, but it is my opinion that such an offence would be a deliberate effort on the part of an individual to topple the present government by either propaganda or more violent means. In other countries these activities are not looked on with favour by the governments involved. Thus, it is asking rather too much of the present Chilean government to tolerate these activities, particularly since the military came to power only a short time ago and after a rather messy civil war. This deals directly with a statement in the letter to Nature regarding the Catholic University. The statement is inaccurate. Only $3.25 \%$ of faculty members were removed after the coup because they did not do teaching and research but engaged exclusively in different forms of political activity. To assume that the rest $(96.75 \%)$ were all right-wing, God-fearing, church-going and thoroughly nice fellows would be naive in the extreme. In fact, many of them have views that would not please the present government. But Admiral Swett has been a careful, intelligent and conscientious administrator who and, if cleared, they have been em- has strived very hard to maintain and improve the present academic structure. He has the confidence and respect of both faculty and students.

With regard to the. Chilcan scientists remaining in the country the following must be said. These people are labouring under very difficult circumstances which are mainly economic. They have very low salaries (which are in line with those of others), mainly because of the difficult economic conditions of the country caused by the previous government; recovery is still very incomplete. For the same reason, funds for research are very limited, and it is very difficult for these people to carry out experiments using modern techniques. Furthermore, subscriptions to journals in libraries are running far behind, also for lack of funds, which makes the situation doubly difficult. Nevertheless, Chilean scientists are trying very hard to maintain a research establishment that is in bad shape although it was flourishing four or five years ago. But there is hope. CONICYT is operating again, fulfilling the purpose for which it was originally created during the Frei administration. Also, the government has rescued the Academy of Sciences from financial disaster. More important is the fact that government authorities are listening and are sympathetic to the plight of the local scientists in terms of improving salaries and making available more funds for research and so on.

Inaccurate letters of the type published in Nature, although well meaning, do not help those still in Chile. They create a distorted image of the country that may prevent foreign help which is badly needed in keeping what is left after the debacle of the past three years. Scientists who remain in Chile are not fascists but people sincerely devoted in pursuing their academic careers and training future researchers. In fact, some have received tempting offers from abroad and have refused to leave the country. They are far more courageous than those who left to practice 'gauchisme de salon'. The latter and their supporters should be more accurate in their statements, as one would expect from scientists, since these shot-gun anproaches only hinder the struggle of dedicated scientists working in a difficult environment. 